\title{
Contested Authenticity Anthropological Perspectives of Pilgrimage Tourism on Mount Athos
}

\author{
Michelangelo Paganopoulos
}

Citation: Paganopoulos,

Michelangelo. 2021. Contested

Authenticity Anthropological

Perspectives of Pilgrimage Tourism on Mount Athos. Religions 12: 229.

https://doi.org/10.3390/rel12040229

Academic Editor: Kiran Shinde

Received: 14 February 2021

Accepted: 21 March 2021

Published: 25 March 2021

Publisher's Note: MDPI stays neutral with regard to jurisdictional claims in published maps and institutional affiliations.

Copyright: (C) 2021 by the author. Licensee MDPI, Basel, Switzerland. This article is an open access article distributed under the terms and conditions of the Creative Commons Attribution (CC BY) license (https:// creativecommons.org/licenses/by/ $4.0 /)$.
Global Inquiries and Social Theory Research Group, Faculty of Social Sciences and Humanities, Ton Duc Thang University, Ho Chi Minh City, Vietnam; michelangelopaganopoulos@tdtu.edu.vn

\begin{abstract}
This paper investigates the evolution of customer service in the pilgrimage tourist industry, focusing on Mount Athos. In doing so, it empirically deconstructs the dialectics of the synthesis of "authentic experience" between "pilgrims" and "tourists" via a set of internal and external reciprocal exchanges that take place between monks and visitors in two rival neighboring monasteries. The paper shows how the traditional value of hospitality is being reinvented and reappropriated according to the personalized needs of the market of faith. In this context, the paper shows how traditional monastic roles, such as those of the guest-master and the sacristan, have been reinvented, along with traditional practices such as that of confession, within the wider turn to relational subjectivity and interest in spirituality. Following this, the material illustrates how counter claims to "authenticity" emerge as an arena of reinvention and contestation out of the competition between rival groups of monks and their followers, arguing that pilgrimage on Athos requires from visitors their full commitment and active involvement in their role as "pilgrims". The claim to "authenticity" is a matter of identity and the means through which a visitor is transformed from a passive "tourist" to an active "pilgrim".
\end{abstract}

Keywords: authenticity; spirituality; Mount Athos; hospitality; pilgrimage tourism

\section{Introduction}

In investigating the dialectics between the concepts of "tourism" and "pilgrimage landscape", and "tourists" and "pilgrims", respectively, this paper uses two key claims that affirm the "sacredness" of pilgrimage tourism: "authenticity" and "spirituality". In doing so, the paper focuses on two rival monastic communities situated on Mount Athos, an autonomous Christian Orthodox monastic republic of twenty self-sustainable monasteries and their settlements, situated in the mountainous peninsula of Chalkidiki in northern Aegean. In the classic terms of Edward Bruner (2005, p. 18), Mount Athos functions as a "touristic borderzone", a crossroad where the monastic and secular worlds meet and reciprocate. At the time of my fieldwork, the estimated number of visitors to Athos was up to 50,000 (Greek newspaper Makedonia, 28 November 2005, p. 31) and reportedly increased to more than 75,000 by $2018^{1}$ (as there is an unknown number of informal visitors whose close relationship to monks overrides formal entry regulations). The paper focuses on the years between 2002 and 2004, which anticipated the rapid increase in the estimated number of visitors to the peninsula of Athos. The paper explores some of the economic solutions given to the challenges represented by the increasing presence of visitors in the daily life of the monasteries, including imposing and reinforcing rules and prohibitions associated with the land, a new timetable and divisions in space, and other "economic" (i.e., compromised) changes and reinvention of practices, such as confession. In turn, the changes in the way the monks relate to their guests affect traditional roles, such as those of the confessor evolving into that of the life-advisor, as well as monastic practices

1 "Elder Ephraim of Mt. Athos speaks with TNH" (10 February 2018). Available online: https://www.thenationalherald.com/archive_church/ arthro/elder_ephraim_of_mt_athos_speaks_with_tnh-19466/(accessed on 2 December 2020). 
relating to these roles, such as confessions evolving into psychoanalytical sessions. By comparing two opposite claims to authenticity by the rival brotherhoods and their followers of the monasteries of Vatopaidi and Esfigmenou, the paper deconstructs the dialectics of Athonian "hospitality" ("filoxenia") on the basis of a set of internal and external reciprocities taking place on the holy grounds of the monasteries between "the worlds of the laity and the celibate monasteries" (Loizos and Papataxiarchis 1991, p. 16).

\section{Fieldwork}

The material derives from my own personal experiences back in 2002 to 2004, following my journeys to two monasteries of Mount Athos. ${ }^{2}$ By asking the permission of the monks, they kindly allowed me to stay for long periods in the monasteries, where I conducted fieldwork in a systematic and methodological way, gathering empirical data using interviews, archive and administrative material. I also extensively participated in the everyday life of the monasteries, while casually talking with visitors and monks. The quality of service and the things expected of me in each monastery revealed to me a very different understanding and ways of offering hospitality ("filoxenia"), one of the main traditional services of the monasteries. Respectively, the means and quality of hospitality I received in each monastery gave me a rare insight into the differences in customization and services offered to visitors. In the monastery of Vatopaidi, the monks agreed for me to stay and conduct my research on the basis that I would fully participate in the liturgical and working life of the monastery. For this reason, my personal "informants" became my "spiritual father" ("pneumatikos pateras") who supervised me during my confessions to him in the night, and the guest-master on duty ("archontaris") who supervised me at work during the day at the guesthouse. By contrast, in the monastery of Esfigmenou, I was not allowed to reciprocate my staying with manual work or confession. The monks of this monastery consider frequent confessions to be a "Western" influence and not as part of their "pure" zealot tradition. In similar terms, I was not allowed to help or contribute in any way for my staying. Rather, I was only meant to pray throughout my staying and take the oath to the "Old Calendarist Church", an ultra-Orthodox sect, as part of this monastery's interpretation of hospitality.

The paper qualitatively compares the customization of hospitality in the two monasteries because they represent two opposite environments whose ethnographic comparison highlights both the heterogeneity and openness in conceptualizing and reinventing the Athonian tradition in terms of its "authenticity". Furthermore, at the time of my fieldwork, major developments took place in Esfigmenou, as the monastery had been placed under embargo (and still remains so) due to its politics outside Athos, which meant that no visitors were allowed to approach its premises. However, many found alternative, and at times, illegal ways of entering the monastery and supporting the monks with their political cause. This raised a public controversy regarding the Esfigmenou's uses of hospitality and legitimacy of services offered by its monks to pilgrims in exchange for ideological loyalty from visitors.

A second reason for reflecting upon the material gathered during this period, i.e., the turn of the millennium, is the beginning of the flourishing of the tourist pilgrimage industry, following the global turn to subjectivity and "spirituality", especially amongst Christians (Speake and Conomos 2005; Speake and Gothóni 2008; and Heelas et al. 2005). The global turn to spirituality saw a sharp rise and development of "pilgrimage tourism" and an ever-increasing interest in religious sites as tourist attractions (Rejman et al. 2016, p. 568). A part of this wider process of "re-enchantment" with religion (Comaroff and Comaroff 2000, pp. 291-343) was the rise of religious tourism, emerging within a

2 As part of my doctoral research, I visited Athos ten times over periods that lasted from four to eight weeks. I wish to kindly thank the monks for their hospitality, discretion, interest, and their general positive input to the research. Trip 1: 19 February 2002 Vatopaidi, Trip 2: 29 November 2002 Esfigmenou, Trip 3: 5 January 2003 Esfigmenou, Trip 4: 25 February 2003 Esfigmenou, Trip 5: 25 March 2003 Vatopaidi, Trip 6: 6 June 2003 Esfigmenou (jumping fence because of embargo), Trip 7: 2 August 2003 Vatopaidi, Trip 8: 12 September 2003 Vatopaidi, Trips 9-10: August 2004 Vatopaidi and Esfigmenou. 
reinvented and personalized market of faith (as in Kim et al. 2020 and Wang et al. 2020). Religious tourism as a pilgrimage experience is a contemporary phenomenon that defies a specific definition due to the intermarriage between tourist and religious experiences (see Tilson 2005, pp. 9-40; Olsen and Timothy 2006, pp. 1-22, and Rejman et al. 2016, pp. 562-75). The rapid changes in customer service in monastic settings reflected upon the wider transformation of the monastic economies from "local economies" into global networks that emerged through the rising "capitalist global economy" (Iossifides 1991, pp. 136-37). They raised dilemmas over how to appropriate "authentic" traditional values against global processes of "de-traditionalization" (Heelas et al. 1996), as a means of preserving both the economic and ritual life of the monasteries (Tanasyuk and Avgerou 2009, online source).

The paper investigates the "authentic" monastic ideal invested in the value of hospitality on Athos, as it emerges out of the dialectics between "re-enchantment" and "detraditionalization" played by the paradoxical presence of visitors in the daily life of the monasteries. In these terms, the comparative material reveals how the openness of sacred sites to the world via the pilgrimage industry raises moralized questions and tensions regarding claims to "authenticity", especially amongst Christians who dogmatically juxtapose money to faith as a means of separating "tourists" from "pilgrims", respectively.

The paper aims to theoretically and empirically contribute to the development of tourism theory for pilgrimage sites, and the wider ongoing discussion over cultural and economic tensions and challenges between development, sustainability, and cultural preservation of monasteries and their authentic way of life. In this context, the paper views hospitality as the grey conceptual area where the monastic and secular worlds meet via a set of reciprocities and mutual agreements. By expanding into personal ("spiritual") and collective (ideological) motivations that attract a visitor to a specific monastery, the paper empirically illustrates: (a) how "objective" mechanisms objectify and naturalize specific cultural settings, by transforming all visitors into "pilgrims" through a cathartic "spiritual" system of practices such as confession; and (b) how, in the politicized context of Esfigmenou, the "pilgrims" then become activists supporting the ultra-Orthodox ideology of the "Authentic Christians", which deems the other monasteries as being less, or even, not being "authentic".

\section{Authenticity and Pilgrimage Tourism}

The millennial turn to subjectivity and "spirituality" saw the rise and development of "pilgrimage tourism" and an ever-increasing interest in religious sites as tourist attractions (Rejman et al. 2016, p. 568). The concept lacks a specific definition due to the ambiguity characterizing the tourist industry in respect to evaluating and integrating subjective motivations and personal experiences as part of the pilgrimage tourist package (see Tilson 2005, pp. 9-40; Olsen and Timothy 2006, pp. 1-22, and Rejman et al. 2016, pp. 562-75). As previous anthropological literature on the subject shows (Morinis 1992), pilgrimage is a process of both self-transformation and self-affirmation via collective participation. Furthermore, beyond the experience of sightseeing, the process formulates social relations made on the way to the site, for example, bonding or arguing between members of the same or a rival group. Ethnographies on Christian pilgrimage show that the journey to a sacred site may become an arena of contestation between rival groups of pilgrims (Eade and Sallnow 1991; Bax 1983, pp. 167-77; Bax 1990, pp. 63-75, and Sallnow 1981, pp. 163-82). ${ }^{3}$ Victor Turner $(1974,1997)$ has extensively discussed the emotional identification with the creation of an identity through transformative rites of passages, such as pilgrimages, highlighting their social value in creating spontaneous cohesion and bonding between members of the same group (i.e., a "communita") via their journey to a pilgrimage site. The

3 Eade and Sallnow (1991), Bax (1983, pp. 167-77, 1990, pp. 63-75), and Sallnow (1981, pp. 163-82) among others, previously challenged Victor and Edith Turner's Durkheimian concept of "communitas" (Turner 1997, 1974) by pointing to the competitive nature of pilgrimage over religious sites. Elsewhere, other examples from rural Greece equally show how such competitive traditional practices define the formation and contestation of collective gendered identities (as in Herzfeld 1985, and Seremetakis 1991) and more recently, matters of historical claims and identity (Solomon 2021). 
journey initiates a process of self-transformation, which involves group experiences and shared memories emerging within the group on their way to a shrine.

Hence, to reduce pilgrimage to a sightseeing experience excludes personal and emotional motivations taking place during a pilgrimage, as well as any "spiritual" esoteric changes that may have an impact on the personality and lifestyle of the traveler in the long term: "rigid dichotomies between pilgrimage and tourism, or pilgrims and tourists, no longer seem tenable in the shifting world of postmodern travel" (Badone and Roseman 2004 , p. 2). Indeed, in their overview regarding the ambiguity of terms such as "religious tourism", Kim et al. (2020, online source) concluded that, "Understandings of religious tourism have evolved beyond pilgrimage and now encompass the meaningfulness of a destination." These may include "individual religious affiliations" and a personal and subjective sense of identity and religiosity associated with the history and vibes of the place (2020, pp. 185-203). As in Bauman's classic analysis of "postmodern religion" (Bauman 1998, pp. 55-78), sacred places project a sense of a concrete identity-in an increasingly fragmented and confusing postmodern world. Accordingly, each monastic community packages a very different, and even antagonistic, "pilgrim experience" to its visitors in relation to the other monasteries, which demands their active involvement, by being fully engaged in the antagonistic nature of the neoliberal market of faith-sometimes even against each other.

Central in enhancing this sense of identity and belonging during a pilgrimage is the "claim to authenticity" of a place and/or a way of life (as in Theodossopoulos 2013, pp. 337-60), which implies the existence of multiple authenticities, or rather, claims and degrees to authenticity. I discuss this in terms of tourist satisfaction in relation to the alleged anticommercial service of the monks to visitors. Studies in tourism, discuss "authenticity" as a means of attraction and satisfaction. Zatori et al. (2018) and Zhang et al. (2018) both quantitatively investigated tourist satisfaction in terms of experience involvement and interactive processes of customization (Zatori et al. 2018, pp. 113-15, and Zhang et al. 2018, p. 927). Zatori et al. pointed to authenticity and memorability as central in offering tourist satisfaction along with the "experience involvement" the hosts allow to their visitors. The latter play an active, "important role in experience formation and value co-creation with the service provider" (Zatori et al. 2018, p. 111). The authors use MacCannell's classic model of "staged authenticity" which develops over three overlapping evaluations: (a) its objectified value; (b) constructed cultural determinants; and (c) in terms of existential authenticity. Wang (1999) and Zhang et al. (2018) associated each stage with a particular trend of thought, i.e., objectivity (focusing on the "objective" value of relics and the landscape); constructivism (the vocation of the place in tourist brochures and its reputation in the market); and postmodernism (offering a transformative experiential process of self-discovery as part of the services), respectively (MacCannell 1973, pp. 589603, and in Wang 1999, pp. 349-70, and Zhang et al. 2018, pp. 927, among others). The first two components of "authenticity" (objective and constructive authenticity) relate to the place and its material objects. Experiential authenticity, on the other hand, focuses on the experiential impact and personal transformation a pilgrimage may have on a visitor in the long term.

In this context, Zatori et al. (2018) defined "customization" as a two-way co-creative process, which emerges in the interaction between visitors and tourist operators during guided tours according to their needs and expectations. In their research on interactive customization, Zatori et al. highlighted the importance involvement plays in forming a positive tourist experience: "The extent to which an experience can engage an individual and how important the experience becomes depends on the extent of the interaction between the company and the customer." (Zatori et al. 2018, pp. 112-13). The interaction and commitment of a pilgrim to a certain setting and/or bonding to a monk can extend to joining their hosts in their ideological battles. "Real-time experiences" (ibid. p. 114) thus co-create the path of self-discovery and self-transformation, which, in turn, enhances the masculine bond between the visitor and the monk in the role of a tourist operator, on 
the basis of their shared and staged "authentic experience". However, since experience and memorability cannot be fully quantitatively evaluated, the existential and influential aspects of authenticity represent a methodological difficulty for the evaluation of pilgrimage tourism in depth (see also Zatori et al. 2018, pp. 114-18; Tilson 2005, pp. 9-40; Olsen and Timothy 2006, pp. 1-22, and Rejman et al. 2016, pp. 562-75).

A second issue associated with the specificity of the landscape is the "anti-commercial" and /or "non-commercial" attitude of the monks of Athos towards the tourist industry, due to the free nature of the "spiritual" services the monks offer to visitors Speake (2002) paints a nostalgic and ideal picture of a kind of premodern experience of living, as if it was extracted from the Byzantine Roman past. Athos offers an "alternative to the rapidly materialism and secularism of modern society" (Speake 2002). On the other hand, Andriotis argues that Athos "has not been developed with the intention of providing a landscape for 'sale' or 'consumption'" (Andriotis 2011, p. 1624). Andriotis then associates the "noncommercial nature" of Athonian Hospitality with the collective feeling of authenticity associated with the sacred landscape., The comparative material of this paper shows that there is no "objective" or "constructive" value given to the Athonian sense of "authenticity". As Cohen (1988, p. 371) exclaimed, "authenticity is conceived as a negotiable rather than primitive concept," which in the context of commoditization in tourism may evolve into various "emergent" authenticities. The way Athonian "authenticity" is marketed in tourist brochures and the web, projects a rather idealist way of reimagining the sacred peninsula in the present time as a means of attraction and tourist satisfaction (Selwyn 1996). The comparison of the interpretation and means of hospitality from Vatopaidi and Esfigmenou show that the vibe of "authenticity" is not a static, homogeneous, or singular tour-de-force, but rather, evolves into emergent authenticities, which may even contradict each other by questioning the "authenticity" of other counterclaims. This contestation then raises dilemmas over what is "authentic" and what may be a "merely spectacle" (as in Kim and Jamal 2007, pp. 181-201).

Accordingly, the paper examines how each monastic community's claim to "authenticity" constitutes an objectified collective feeling (than a historical fact), socially emerging out of the dialectics of everyday life. In this context, the claim to authenticity may become a vehicle of a certain ideology that constitutes the vocation of each monastic institution outside Athos. The mutual existence of a number of authenticities further reveals the heterogeneity found on Athos in terms of customer categorization, offered services, and means of attraction, all of which depending on the dialectics between each particular monastic institution and its material history (objective and constructive authenticity), and the personalized services its monks offer to their visitors (existential and influential authenticity). The dialectics that determine this process of objectifying the value of "authenticity" are: [THESIS] Objective/Constructive authenticity (PLACE) vs. [ANTITHESIS] existential/influential authenticities $($ PERSON) $=>$ [EMERGING SYNTHESIS] Objectified Value of a pilgrimage landscape.

\section{Athos: An "Authentic" Landscape and Way of Life}

In my discussions with monks during my fieldwork, they considered themselves to be life-long visitors to the "Garden of the Mother of God" ("o kipos tis Theotokou") or the "Garden of Virgin Mary" ("o Kipos tis Parthenou"). They believe that Mary is the owner ("ktitorissa") of the peninsula, whose omnipotent presence traditionally establishes a "spiritual" way of monastic life ("pneumatiki zoe") associated with the Holy Mount, as opposed to the "materialist" way of secular life associated with the "worldly world" ("kosmikos kosmos") outside Athos. This separation is traditionally affirmed by the rule of Avaton ("No Trespassing") referring to the prohibition of all females from the peninsula, which dates back to the very foundation of the republic in the 9th century (Papachrysanthou 1992; Paganopoulos 2007, pp. 122-33, 2020, pp. 66-87). In this context, the peninsula's "sacredness" demonstrates the Durkheimian understanding of monastic life as a "sacred" way of life (Durkheim [1912] 1995, pp. 37-42; Ross 1991, p. 100, and Paganopoulos 2007, 
pp. 123-24, 2020, pp. 66-68). The exceptional "spirituality" associated with the peninsula is legally affirmed under the "spiritual" protection of the "Ecumenical Patriarchate" (as per paragraph 1 of Article 105 of the Greek Constitution, see also Hellenic Parliament website). ${ }^{4}$ In 1979, the European Community further ratified the autonomous status of the republic, "justified exclusively on grounds of a spiritual and religious nature". ${ }^{5}$ By 1992, the republic was further included in and funded by the UNESCO World Heritage Program for the preservation of its "authentic" way of life. ${ }^{6}$

UNESCO's inclusion of Athos as a World Heritage Site enhanced the peninsula's worldwide reputation for offering a personalized "authentic" experience of monastic life to its visitors, described in online blogs as "mystical", "spiritual", and "emotional", "[ ... ] difficult to explain unless you have experienced that once in your life" (blogger Christian Zocca, 20 December 2020). ${ }^{7}$ In breaking down this claim to "authenticity" into its components, Andriotis (2011, pp. 1613-33) made the correlation between "genres of authenticity" of pilgrimage landscapes (Gilmore and Joseph 2007), and the core elements of experiencing the sacred Athonian site (Andriotis 2009, pp. 64-84). For Andriotis, a pilgrimage landscape is an "experiential cultural space" (2011, p. 1614) consisting of five corresponding elements: natural/spiritual, original/cultural, exceptional environmental/referential/secular, and influential/educational, respectively. In deconstructing the "authentic" experience of visiting Athos, Andriotis highlighted a dialectical tension between supply and demand in terms of "objective authenticity" and "existential experience", respectively (Ibid). In this dialectical context, the "objective authenticity" of a place or an object depends on a Durkheimian collective recognition of "authenticity" as a social phenomenon: "[ ... ] the authentic experience is caused by the recognition of the toured objects as "authentic" [ ... ] not because they are inherently authentic but because they are constructed as such in terms of point of view, beliefs perspectives or powers" (Wang 1999, p. 351 cited in Andriotis Ibid., and also in Belhassen et al. 2008, p. 686).

Most of the visitors that I engaged with during my fieldwork, tended to highlight that they had travelled to Athos to get a taste of the monasteries' way of life as "it was a thousand years ago". This shared motivation revealed a collective nostalgia for a golden Byzantine Empire, or "structural nostalgia" in Herzfeld's terms of a "longing for an age before the state" (Herzfeld 1997, p. 22): an imagined and protected masculine space (which traditionally excludes the presence of women), where only male visitors can nostalgically and religiously experience an authentic Byzantine living past, by engaging with monks in their activities (as also in Andriotis' example of Athonian "original authenticity", 2011, p. 1622). Furthermore, the pan-Orthodox and international vocation of Athos to Christians from across the globe responds to ideals of a "Byzantine universalism" beyond the boundaries of modern nation states (as in Tzanelli 2008, pp. 141-50). Objects of veneration such as miraculous relics and ancient icons kept in monasteries (as in Andriotis' example of "referential authenticity" 2011, pp. 1625-26) attract thousands of visitors every year from across the Orthodox spectrum and beyond, supporting an informal industry of "pilgrimage tourism" that has globally emerged with an ever-increasing interest in visiting religious sites as tourist attractions (Rejman et al. 2016, p. 568). Vice versa, this nostalgic return to a reinvented Imperial past, associated with the sacredness of the landscape, enhances a

4 Available at: http://home.lu.lv/ rbalodis/Konst\%20tiesibas/Federalisms/Feder_Unit\%C4\%81r\%C4\%81_Grie\%C4\%B7ija_Konstitucija.pdf; https: //www.hellenicparliament.gr/en/Vouli-ton-Ellinon/To-Politevma/Syntagmatiki-Istoria/ (accessed on 17 January 2019).

5 Source: UNESCO/CLT/WHC (Official Journal L 291, 19/11/1979 P. 0186). Available online: http:/ / whc.unesco.org/en/list/454.11979H/AFI/ DCL/04/ (accessed on 17 January 2019).

6 UNESCO's "World Heritage List" describes Athos in terms of its "Authenticity: "The property reflects adequately the cultural values recognized in the inscription criteria through the setting of the monasteries and their dependencies, together with the form, design and materials of the buildings and farms, their use and function, and the spirit and feeling of the place. Mount Athos has an enormous wealth of historic, artistic and cultural elements preserved by a monastic community that has existed for the last twelve centuries and constitutes a living record of human activities". Available online: https://whc.unesco.org/en/list/454/, and also see "World Heritage Data Sheet" at https://yichuans.github.io/datasheet/output/ site/mount-athos/ (accessed on 2 December 2020).

7 "Have a Mystical Experience in Halkidiki Mount Athos" (20 December 2020) in Zocca, Christian's blog "Trips Are Over." Available online: https://tripsareover.com/en/greece/experiences/have-a-mystical-experience-in-halkidiki-on-mount-athos/ (accessed on 2 February 2021). 
deeper collective feeling of authenticity springing out of the separation of monastic from secular life outside the border of the republic.

For a visitor, this "'passage from the profane to the sacred' [ ... ] serves as a journey to the world of Byzantium as well as an initial signifier of natural authenticity" in Andriotis' words (2011, p. 1620). Everyday life inside the monasteries follows the coenobitic (communal) rule introduced by St Athanasius the Athonite (920-1003AC) a millennium ago. ${ }^{8}$ The peninsula lacks infrastructure, offering limited access to the monasteries. Although some monasteries use photovoltaic energy and generators for electricity, the majority of smaller settlements have no electricity, using instead oil lamps and stoves for heating. There are no asphalted roads or electric wires connecting them, but only paths crossing the thick forest leading to the southern cliffs of the peninsula. In their accounts, the monks live a "symbiotic" way of living within nature, which is directly associated with the sacredness of the landscape (Paganopoulos 2020, pp. 66-67). The monastic coenobitic program, timetable and activities follow the change of winter and summer solstices and natural succession of night and day. Since the nights are longer in the winter, the monks spend most of their time in their cells praying and "spiritually" cultivating their monastic self in privacy. In the summer, when the days are longer and warmer, they place more emphasis on daily activities and labor in the fields and the churches. This "symbiosis", therefore, combines traditional practices of faith with agricultural activities, naturalizing the presence of the monks and the monasteries as "natural" parts of the sacred landscape (as also in Andriotis' example of "natural authenticity", 2011, p. 1621).

The collective feeling of "authenticity" is central in the vocation of Athos in the Christian world. The thirst to taste the "authentic" life annually attracts thousands of visitors to Athos, who contribute both to the economy of the monasteries and to the entire local area situated in the touristic peninsula of Chalkidiki, north Greece. In this respect, the traditional prohibition of all females from Athos has been "economically" compromised by the development of an alternative sightseeing industry for "visiting" the monasteries. For example, private cruise companies offer to both men and women a "short pilgrimage and cultural break" as a "spiritual sailing experience" ${ }^{\prime \prime}$ around the peninsula for sightseeing without having to step on ground but remaining in the boat ("floating tourism", Kotsi 1999, pp. 5-20; Kotsi 2012, p. 154). Another example of reinvention of tradition by a younger generation of monks was the development of the traditional symbiotic relationship to the landscape towards a focus on ecological sustainability. The international group "Friends of Mount Athos" (FOMA) established in the 1990s an annual "spiritual ecology camp" taking place in the monasteries of Vatopaidi and Simonopetra. It consists of "a 12-day programme of activities that combine care of the environment on Mount Athos with the spiritual benefits gained from pilgrimage there and participation in the life and prayer of the monasteries". ${ }^{10}$

\section{Accommodation in Vatopaidi}

In general terms, the customer service the monasteries offer to visitors is an outcome of their strict internal hierarchical organization. In my very first visit to the monastery of Vatopaidi, for example, back in September 2002, it became evident to me that it is a

8 St. Basil's coenobitic (communal) mode of life refers to a communal type of monastic living in which its members share spiritual and working labor, food and clothing, hierarchy and egalitarianism, rules and timetable, practices of faith and common spaces (Malavakis 1999 and Vergotis 1995, p. 126).

9 Advert by “All in Bluesive Private Cruises." “Mount Athos: Special, Spiritual Sailing Experiences.” Available online: https://allinblusive.co.uk/ blog/mount-athos-special-spiritual-sailing-experience/ (accessed on 2 February 2021).

10 Available online: https://athosfriends.org/visiting/join-the-syndesmos/ and https://athosfriends.org/events/2020-spiritual-ecology-camp-onmount-athos/ (accessed on 16 November 2020). Yet, the landscape is not as "authentic" as presented to visitor-pilgrims, as it has transformed several times in the past, mainly because of the great fires of 1580, 1622, 1891 (Eleseos and Papaghiannis 1994, p. 48), and most recently, in August 1990, and February 2004, and is constantly changing. Eleseos and Papaghiannis identified as the main ecological problem the desertification of the land, especially at the southern areas of the peninsula, because of the great fire of 1990 and over-exportation of wood (Ibid, pp. 51-54). The two monks further observed that "the introduction of telecommunications, water pipes, machines, and electrical generators into the peninsula threat the calmness, form and function of the environment... The pollution of the space from concrete and liquid waste could be out of control" (Ibid, $43, \mathrm{my}$ translation from Greek). 
highly organized environment. The presence of guests was limited to the guesthouse in the eastern wing of the monastery, the Chapel of the Holy Girdle of Mary (the item that most visitors travel to venerate), the Refectory and the Catholicon (main church) in the center of the monastic complex, and the northern wing of the guesthouse (dormitory). The rooms are decorated with warm red carpets, and beautiful and expensive icons of saints and/or Greek national heroes. The first and second floors have up to eight beds. This area is reserved for common visitors. The third floor is far more luxurious, with big rooms of single or two beds reserved for the rich and powerful "friends" of the monastery, that is, mainly donators, politicians, and Archimandrites. At the top, where my room was situated, was used for visitors who planned to stay for longer periods and possible candidates. All rooms have electricity and hot water throughout the day produced by two generators. The deacons on duty are responsible for changing the bed sheets and pillows on a daily basis. By contrast, the cells of the monks are of a much poorer condition-without electricity or running water situated at the southern wing of the monastery clearly separated from the visitors' area. Visitors are not allowed to access that area, so that they do not disturb the private and traditional way of life of the monks.

The presence of visitors in the daily life of the monasteries is a major challenge to the monks and their traditional obligation, associated with the landscape's sacredness, to offer hospitality. Many visitors, especially newcomers, do not behave like "pilgrims" because of their tourist mentality and ignorance of the rules associated with the Avaton and/or ritualized daily life. For this reason, the elders have established a set of rules on how to accommodate visitors (affirmed in the Charter of Athos of 1926) and reinvented traditional monastic roles, such as those of the guest-master ("archontaris") and sacristan ("vemataris") according to the visitors' present needs. Both are responsible in welcoming the visitors, setting the timetable and rules of conduct and contact while staying in the monastery, and then introducing them to the monastery's history and tradition, including an exhibition of the holy relics.

The rules demonstrate an economic quality with its own "logic" of "economic" restrain, from food abstinence in the rooms, to the prohibitions of wearing a t-shirt, talking on mobile phones, taking pictures of the monastery without the permission of the Abbot or swimming - as this is not meant to be a touristic place like the rest of Chalkidiki. Under the omnipotent gaze of Mary, visitors rarely break the rules, and if so, they get blacklisted by the Athonian authorities and are not allowed to revisit the place for a certain period. In this context, such restrictions exhibit another sense of "economy" (from the Greek word "ecos" and "nomos" meaning "Law of the House"): economy in how one is dressed, and economy in how one uses technology inside the monasteries. In this sense, visitors are integral in the economical organization of the monasteries. Visitors buy copies of holy items, books and CDs from the monastery's gift shop usually situated next to the main gate or inside the guesthouse. In exchange for their staying, some visitors who spend longer periods there engage in voluntary work, for example, packaging handmade products, rosaries and candles, CDs with the choir, and books on the lives of charismatic elders, in order to distribute them to their local churches and religious shops outside Athos. Such economic arrangements mediate between the secular world and prohibitions associated with the land, guaranteeing the naturalized moral order of the monasteries within the wider landscape reinforced by a collective feeling that Mary is constantly watching them.

In the same way they divide the spaces of the monastic buildings in terms of accessibility, the monks keep the monastic and secular worlds separated via two parallel internal hierarchical structures: an informal spiritual hierarchy of elders and deacons running parallel to more institutionalized forms of rank of priests and priest-deacons (Sarris 2000, pp. 8-9; Paganopoulos 2009, pp. 364-66). The structural separation of the public (daily activities including accommodation of visitors and addressing the material needs of the monastery) from the monks' private life (spiritual activities that take place in the night addressing the spiritual needs of the monastic self) remain integral in the monasteries' focus in accepting and accommodating their visitors. These economic compromises are 
integral in the traditional life of the community. The accommodation of visitors within the strict hierarchy of the monastery is a precondition in order to include them as "pilgrims" regardless of their background or degree of faith-by keeping their presence separate from the monks and their working and private areas, in terms of rules and prohibitions, accessibility, and manner of conduct. This form of control is a precondition for entering a monastery in the first place, including the limited number of visitors (it takes up to three months to gain a permission to enter the republic by the Athonian authorities) ${ }^{11}$ : "The number of visitors permitted on the Holy Mountain at any time is tightly restricted and all visitors are, by definition, pilgrims. Whatever your reason for visiting them, the monks will welcome you as a pilgrim".12 As Gothóni exclaims, "while many visitors on their inward journey admit they are just taking a look, when they return, they realize they have made a pilgrimage" (Gothóni 1994, p. 179, cited by Andriotis 2009, p. 79). So, how does this metamorphosis of "tourists" into "pilgrims" take place (in order for them to be accepted by the community)?

\section{Personal Services}

In my discussions with visitors, many of them visited Athos not only for sightseeing or tasting Byzantine life, but also for personal reasons, in the lookout for a "spiritual father" ("pneumatikos pateras") who would help them in matters over their personal life outside Athos (Paganopoulos 2009, pp. 375-77, and also in Andriotis' example of "influential authenticity" 2011, pp. 1626-7). In the words of Abbot Ephraim of Vatopaidi, one "important" service the monks offer today is giving visitors advice regarding issues in their personal secular life outside Athos: "When lay people visit the monastery, they take away the example of the monks or nuns, their words, their silence, their prayer, their whole attitude and religious disposition. These lay people take leaven, they are nourished spiritually and recharge their batteries [ ... ] Then when they return to their family 'in a different form,' the other members will also benefit spiritually". ${ }^{13}$ In this context, the monks act as "brokers of the tourist experience" (as in Zatori et al. 2018, p. 112) between the secular and monastic worlds. Their mediatory role allows them to both contain the "authentic experience" but also influence their visitors beyond their visit ("influential authenticity", as in Andriotis 2011, p. 1626). This close engagement with the visitors takes place via personalized services and cathartic practices of faith, such as confession. The rite has both a cathartic and a supervising role, as, on the one hand, through the rite each visitor is cleansed in order to be allowed to stay as a means of entering the hierarchy and communal rule, and on the other, by allowing the impersonal institution of the "Monastery" to enter into the personal life of each visitor. This exchange of private worlds (monastic and personal) is necessary, especially for those who wish to stay for longer periods in a monastery, as a means of allowing and accepting them in the monastery's daily life. Furthermore, the request to confess on arrival is necessary for allowing them to become a pilgrim, thus drawing a line between those who have confessed and can stay longer and those tourists who have to leave after a few days defining the quality of service they receive.

An important aspect of confession is that the spiritual fathers have to show "economy" towards the visitors by considering each one's background. The "spiritual fathers" ("pneumatikoi pateres") cannot ask of a first-time visitor the same attention or show the same strictness as they do to someone who is a more frequent visitor. In this "economical" manner, the spiritual fathers reinvented confessions according to our times and the needs of their visitors as a kind of psychoanalytical session, making them integral and relevant to

11 "A maximum of 120 Orthodox Christian visitors are allowed per day, whereas foreigners of other religious affiliations are limited to 14 per day. These limits do not include persons that have explicit invitations from the monasteries." From "Visiting Mount Athos" in Mount Athos: The Holy Mountain official website Available online: http:/ / www.macedonian-heritage.gr/Athos/General/Visiting.html (accessed on 16 March 2021).

12 In Greek, the word "pilgrims", i.e., "proskynites" literary means "worshippers. Available online: https://athosfriends.org/pilgrims-guide/ (accessed on 11 November 2020).

13 “Elder Ephraim of Mt. Athos speaks with TNH" (10 February 2018). Available online: https://www.thenationalherald.com/archive_church/ arthro/elder_ephraim_of_mt_athos_speaks_with_tnh-19466/(accessed on 2 December 2020). 
each visitor's secular daily life. During confessions, the priest-monk offers his advice and a set of "exercises" (askesis, root to the word "ascetic") focusing on prayer, along with his moral advice on secular issues such as sexual intercourse outside marriage, advice over family issues, etc. Over time, frequent visitors develop a trusting relationship with their "spiritual father" that can be life-changing. Furthermore, the confession made me feel as being supervised by the community as a whole, as my private life became public property through my confession to my "spiritual father", who then confessed his sins to the Abbot. In this hierarchical manner, the monks both allow and supervise the presence of visitors into their hierarchical system. The spiritual father functions as a mediator between the individual's world and the sacred place, one that includes both the monastery and the community as a whole. Vice versa, the process of confession aims to gradually transform the "tourist" to a "pilgrim" within the moralized and naturalized terms determined by the sacredness given to the place. The connection between the self and the community is then affirmed and celebrated with the reception of the Divine Eucharist every Sunday by the whole community in a Durkheimian unificatory manner.

\section{Contested Hospitality in Esfigmenou}

Five kilometers north of Vatopaidi is the monastery of Esfigmenou, "the last tower of zealots" as it is known on social media. Esfigmenou is a self-proclaimed "zealot" brotherhood that belongs to the "Old Calendarist Church" ("Palaioimerologites"), an international sect called the "Authentic Orthodox Christians" whose members follow the "old" Julian calendar as a demonstration of their ultra-Orthodox faith (Moss 2010, pp. 3-59; Sidiropoulos 2000, p. 173; Taft 2013, pp. 23-44; Speake 2002, p. 146, and Demacopoulos 2017, pp. 482-89). The monastery of Esfigmenou is at the center of this network, which includes a number of renegade subgroups, such as the "Russian Orthodox Church Outside Russia" (ROCOR) in the US, as well as more localized far-right religious groups in the Balkans, such as those of "St Basil" and "ELKIS" in Thessaloniki, Greece (Moustakis 1983). Since 1973, a black banner hangs from Esfigmenou's highest tower calling for "Orthodoxy or Death". Since February 2003 (the time I was inside for my fieldwork), the monastery has been put under embargo by the Athonian authority and the police, an embargo that lasts to this day. According to the Eviction Note, issued on 5 February 2003 by the Athonian authorities, the new Zealots of Esfigmenou and their followers "have willingly cut themselves off all Orthodox Churches in order to join the so-called 'Authentic Orthodox Christian' group, and only give Holy Communion to members of the Old Calendarist Church" ${ }^{14}$ Other transgressions include not commemorating the Ecumenical Patriarchate in their prayers, and engaging in a persistent political activism with their followers inside and outside Athos.

Inevitably, the circumstances and restrictions imposed by the embargo define both the monastic service the monks offer to their visitors, and vice versa, the quality of visitors the monastery receives according to a specific ideological orientation and the institution's reputation in the Orthodox world. In my discussions with visitors in Esfigmenou, I could not help but notice a kind of "persecution complex" collectively expressed as an "apocalyptic mission" (as in Hall 1997, p. 361). The embargo against the monastery was a personal matter for them, in many ways symbolizing their own life struggle against society and their personal demons inside them. The embargo did not prevent them from climbing over the fence that separates Athos from Greece and illegally walk to the monastery via the thick forest. Ironically, the stricter the embargo becomes, the bigger the reputation of the monastery gets, and consequently, the more visitors it receives. Most of the visitors I met in Esfigmenou were social outcasts stigmatized by poverty, drug addicts and alcoholics trying to rehabilitate from their addiction, illegal immigrants and fugitives from the law, right-wing extremists and followers of the brotherhood's neo-fundamentalist dogma of the

14 Update issued by the Holy Committee informing pilgrims the reasons for the 2003 embargo (28 January 2003, p. 2, my translation from Greek]. See also pamphlet The Truth of the Case of the Occupiers of Esfigmenou. Mount Athos, Karyes. 
"Old Calendarist Church". They had arrived from across the spectrum of the Orthodox world and joined one of the seventeen segregated groups of the monastery according to their nationality and language headed by an elder.

The loose hierarchy of the monastery was also evident in spaces such as the refectory where monks and visitors shared the same tables according to their nationality (rather than sitting separately from the monks as in the other monasteries). No confessions or frequent reception of the Holy Communion were offered to visitors, since the "Old Calendarist" dogma considers frequent repetition of practices and values such as of obedience as a means of keeping visitors under the control of the "Papic" West (sic). In open discussions with visitors, the monks of Esfigmenou often used the neighboring monastery of Vatopaidi as an example of "betraying" monks who have distorted the "authenticity" of Athonian life threatening to distort the "sacred tradition" from the inside: "They will even allow women to visit with their families and make this place a hotel like the rest of Chalkidiki" one Elder of Esfigmenou exclaimed to me. ${ }^{15}$ Instead, the type of exchanges in Esfigmenou exclude money. During the embargo, visitors supported the monks' ideological cause in numbers, bringing with them food, medicine and supplies. The active involvement of the visitors of Esfigmenou in the monastery's daily life was essential for the survival of the monks. Due to the embargo, visitors in Esfigmenou can stay indefinitely, as long as they take the oath to the "Old Calendarist" dogma (instead of confession).

Hence, while in Vatopaidi visitors transformed into "pilgrims" via reinvented practices of faith, such as confession, in Esfigmenou visitors actively participate in daily life by following and fighting for the monastery's ultra-Orthodox ideology inside and outside Athos, and against the Athonian authorities and the Ecumenical Patriarchate. However, for the Vatopaidians, the over-emphasis of Esfigmenou on poverty and struggle undermined the "spiritual life" of Athos and its guarantor, the authority of the Ecumenical Patriarchate. They see Esfigmenou's passionate engagement with the dogma of "True Faith" as against the teachings of the Fathers that promote "silence" ("Hesychasm") and peaceful harmony within the self, as well as towards others and the natural environment. The Vatopaidians also believe that it is their main responsibility to preserve and develop the monastic institutions-for which they need funding and influence outside Athos. By refusing to engage with the rest of the Athonian community, the monks of Esfigmenou "let their monastery (Esfigmenou) rot" one Elder of Vatopaidi told me. He continued: "You know what they (monks of Esfigmenou) do? They sent their visitors dressed up in poor clothes to ask for water, because they already know that we will not offer them because they are all a sect. Then they go around on Athos and in Thessaloniki and complain that we do not honour hospitality." (Paganopoulos 2012, pp. 273-74, Fieldwork Notes). Here then, the traditional monastic value of "filoponia", meaning "friend-with-pain", which both monks and their followers publicly exhibit in Esfigmenou, is practiced the wrong way because of its excessive use as a way to publicly demonstrate "True Faith".

It is important to note that from the Vatopaidian perspective, it is not the value or the practice that are wrong, but the way they are interpreted and the style of performance (Vatopaidian spiritual setting for visitors to renew themselves versus Esfigmenou's setting offering to visiting pilgrims the means for self-martyrdom against the world). This difference in style reflects upon the differences in customization and the way the monks relate to their visitors, and vice versa, the way the visitors relate to the monks. While in Vatopaidi, the processes of interactive customization and male bonding between monks and visitors

15 The prohibition of women remains a topic of contestation and discussions in the European Parliament over the abolition of the Avaton on the basis of the Charter of Fundamental Rights of the European Union, as per article 23 regarding the "Equality Between Men and Women". In 2003, a number of members of the European Parliament raised the issue, including Maria Izquierdo Rojo's (PSE) written question P-0556/03 to the Commission (20/2/2003) published the Official Journal of the EU 2004/C 58 E/023, and Anna Karamanou's and the Chairperson of the Committee of Women's Rights and Equal Opportunities' report in July 2003 [See Swiebel and Rojo reports 2003]. See also Corrigendum to Directive 2004/58/EC of the European Parliament and of the Council of 29 April 2004 on the right of citizens of the Union and their family members to move and reside freely within the territory of the Member States amending Regulation (EEC) No 1612/68 and repealing Directives 64/221/EEC, 68/360/EEC, 72/194/EEC, 73/148/EEC, 75/34/EEC, 75/35/EEC, 90/364/EEC, 90/365/EEC and 93/96/EEC (Official Journal of the European Union L 158 of 30 April 2004), and L 229/38 EN Official Journal of the European Union 29.6.2004 'RIGHT OF EXIT AND ENTRY to all Union citizens' (CHAPTER II: Article 4). 
take place in "spiritual" passionless ways (confession, private prayer, contemplation), in Esfigmenou, customization is marked by poverty and the public and passionate struggle against both the body and the world. Accordingly, catharsis in Vatopaidi is a private and "spiritual" matter of the soul, but in Esfigmenou is a public matter of struggle against the flesh in a zealot way. The way the monks of each institution relate to their visitors (spiritual versus zealot manner) defines their customer service in terms of the quality of "authentic experience" they are offering, as part of the specific vocation of their monastery in the Orthodox world.

\section{Conclusions}

The material of this paper empirically compared the customization and involvement experience of visitors in two rival monasteries of Athos, demonstrating their opposite understandings regarding the role and means of offering monastic hospitality to the world. The different quality of services offered to, and opposite styles of interacting with visitors, revealed the heterogeneity in the interpretation and practice of hospitality in each monastery, in direct relation with their external vocation in the Orthodox world. In these terms, the paper compared the contrasting internal regimes of Vatopaidi and Esfigmenou as spiritual and ideological environments, respectively. Accordingly, the paper discussed how the monks of each monastery relate to their visitors in their own idiosyncratic manner. he comparison qualitatively unpacked the third element that constitutes the concept of "staged authenticity" (objective, constructive, and existential) in its spiritual and ideological components. It investigated how the claim to "authenticity" is an open arena of contestation and negotiation regarding appropriations of the past in the present time, such as the emergence of the phenomenon of pilgrimage tourism. By contextualizing the pilgrimage tourism of Athos within the world system, the paper further showed how traditional customization has rapidly evolved into a variety of styles and services offered by the monks to visitors, in relation to the global phenomena of re-enchantment with sacred landscapes and emergence of the personalized market of faith.

Funding: This research received no external funding.

Institutional Review Board Statement: Ethical review and approval were waived for this study, due to granted anonymity, transparency in fieldwork conduct, and active involvement of informants who kindly offered material and participated in this research.

Informed Consent Statement: Informed consent was obtained from all subjects involved in the study.

Data Availability Statement: The data presented in this study are openly available in Goldsmiths Research online, under License Creative Commons Attribution Non-commercial No Derivatives, at http:/ / research.gold.ac.uk/id/eprint/6537/ (accessed on 23 March 2021). Item ID: 6537.

Conflicts of Interest: The author declares no conflict of interest.

\section{References}

Andriotis, Konstantinos. 2009. Sacred Site Experience-A Phenomenological Study. Annals of Tourism Research 36: 64-84. [CrossRef]

Andriotis, Konstantinos. 2011. Genres of Heritage Authenticity. Denotations from a Pilgrimage Landscape. Annals of Tourism Research 38: 1613-33. [CrossRef]

Badone, Elen, and Sharon Roseman, eds. 2004. Intersecting Journeys: The Anthropology of Pilgrimage and Tourism. Chicago: Illinois UP.

Bauman, Zygmunt. 1998. Postmodern Religion? In Religion, Modernity and Postmodernity. Edited by Paul Heelas, David Martin and Paul Morris. Massachusetts: Blackwell Publishers, pp. 55-78.

Bax, Max. 1983. US Catholics and THEM Catholics in Dutch Brabant: The Dialectics of a Religious Factional Process. Anthropological Quarterly 4: 167-78. [CrossRef]

Bax, Max. 1990. The Madonna of Medjugorgje. Anthropological Quarterly 2: 63-75. [CrossRef]

Belhassen, Yavin, Kellee Caton, and William Stewart. 2008. The search for authenticity in the pilgrim experience. Annals of Tourism Research 35: 668-89. [CrossRef]

Bruner, Edward. 2005. Culture on Tour: Ethnographies of Travel. Chicago: University of Chicago.

Cohen, Erik. 1988. Authenticity and Commoditization in Tourism. Annals of Tourism Research 15: 371-86. [CrossRef] 
Comaroff, Jean, and Jean Comaroff. 2000. Millennial Capitalism: First thoughts on a Second Coming. Public Culture 12: $291-343$. [CrossRef]

Demacopoulos, George. 2017. 'Traditional Orthodoxy' as a Postcolonial Movement. The Journal of Religion 97: 475-99. [CrossRef]

Durkheim, Emile. 1995. The Elementary Forms of Religious Life. Translated by Karen E. Fields. New York: Free Press. First published 1912.

Eade, John, and Michael Sallnow. 1991. Contesting the Sacred: The Anthropology of Christian Pilgrimage. Chicago: University of Illinois.

Eleseos, Priest-Monk, and Priest-Monk Papaghiannis. 1994. Natural environment and monasticism: Preserving Tradition in the Holy Mount. Athens: Goulandri.

Gilmore, James, and Pine Joseph. 2007. Authenticity: What Consumers Really Want? Boston: Harvard Business School Press.

Gothóni, René. 1994. Paradise within Reach: Monasticism and Pilgrimage on Mt Athos. Helsinki: Helsinki University Press.

Hall, John. 1997. Apocalypse at Jonestown. In Magic, Witchcraft, and Religion, 4th ed. Edited by Arthur Lehmann and James Myers. London and Toronto: Mayfield, pp. 353-64.

Heelas, Paul, Scott Lash, and Paul Morris, eds. 1996. Detraditionalization. Massachusetts and Oxford: Blackwell.

Heelas, Paul, Woodhead Linda, Seel Benjamin, Szerszynski Bronislaw, and Tustin Karin. 2005. Why Religion Is Giving Way to Spirituality. Maiden, Oxford and Victoria: Blackwell.

Herzfeld, Michael. 1985. The Poetics of Manhood. Princeton: Princeton UP.

Herzfeld, Michael. 1997. Cultural Intimacy: Social Poetics in the Nation-State. New York: Routledge.

Iossifides, Marina. 1991. Sisters in christ: Metaphors of kinship among greek nuns. In Contested Identities: Gender and Kinship in Modern Greece. Edited by Peter Loizos and Evthymios Papataxiarchis. Princeton: Princeton UP, pp. 135-55.

Kim, Hyounggon, and Tazim Jamal. 2007. Touristic quest for existential authenticity. Annals of Tourism Research 34: 181-201. [CrossRef]

Kim, Bona, Seongseop Kim, and Brian King. 2020. Religious Tourism Studies: Evolution, progress, and future prospects. Tourism Recreation Research 45: 185-203. [CrossRef]

Kotsi, Filareti. 1999. The enchantment of a floating pilgrimage. The case of Mount Athos, Greece. Vrijetijdstudies 17: 5-20.

Kotsi, Filareti. 2012. Mount Athos: Development policies for short term religious tourism. International Journal of Tourism Anthropology 2: 149-63. [CrossRef]

Loizos, Peter, and Evthmios Papataxiarchis, eds. 1991. Introduction. In Contested Identities: Gender and Kinship in Modern Greece. Princeton: Princeton UP, pp. 3-26.

MacCannell, Dean. 1973. Staged authenticity: Arrangements of social space in tourist settings. American Journal of Sociology 79: 589-603. [CrossRef]

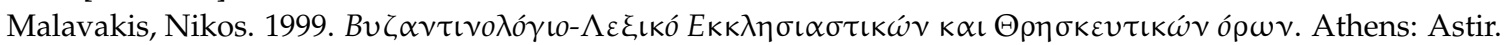

Morinis, Alan, ed. 1992. Sacred Journeys: The Anthropology of Pilgrimage. Westport and London: Greenwood Press.

Moss, Vladimir. 2010. Thirty Years of Trial: The True Orthodox Christians of Greece, 1970-2000. East House, Beech Hill, Mayford, Woking and Surrey: Holy Great Martyr and Healer Panteleimon. Available online: http:/ /www.orthodoxchristianbooks.com/ downloads /257_THE_TOC_OF_GREECE_1970_2000.pdf (accessed on 23 March 2021).

Moustakis, Giorgos. 1983. The Birth of Christian-Fascism in Greece. Athens: Kaktos.

Olsen, Daniel, and Dallen Timothy. 2006. Tourism and religious journeys. In Tourism, Religion and Spiritual Journeys. Edited by Dannel Timothy and Daniel Olsen. Abingdon: Taylor \& Francis eLibrary, pp. 1-22.

Paganopoulos, Michelangelo. 2007. Materializations of Faith on Mount Athos. In Material Worlds. Edited by Rachel Moffat and Eugene de Klerk. Newcastle: Cambridge Scholars Publishing, pp. 122-3.

Paganopoulos, Michelangelo. 2009. The concept of Athonian Economy in the Monastery of Vatopaidi. Journal of Cultural Economy 2: 363-78. [CrossRef]

Paganopoulos, Michelangelo. 2012. The Land of the Virgin: An Ethnography of Monastic Life on Athos. Ph.D. dissertation, Goldsmiths, London. Available online: http:/ / research.gold.ac.uk/6537/ (accessed on 26 October 2019).

Paganopoulos, Michelangelo. 2020. Being and Becoming a Monk on Mount Athos: An Ontological Approach to Relational Monastic Personhood in the "Garden of the Virgin Mary" as a Rite of Passage. Open Theology 6: 66-87. [CrossRef]

Papachrysanthou, Dionysia. 1992. Athonian Monasticism: Principles and Organization. Athens: National Bank of Greece.

Rejman, Krzysztof, Piotr Maziarz, Cezary Andrzej Kwiatkowski, and Małgorzata Haliniarz. 2016. Religious tourism as a tourism product. World Scientific News 57: 562-75. Available online: http://www.worldscientificnews.com/wp-content/uploads/2016/0 6/WSN-57-2016-562-575.pdf (accessed on 30 November 2020).

Ross, Ellen. 1991. Diversities of Divine Presence: Women's Geography in the Christian Tradition. In Sacred Places and Profane Spaces: Essays in the Geographies of Judaism, Christianity, and Islam. Edited by J. Scott and P. Simpson-Housley. New York: Greenwood Press, pp. 93-114.

Sallnow, Michael. 1981. Communitas Reconsidered. MAN 16: 163-82. [CrossRef]

Sarris, Marios. 2000. Some Fundamental Organizing Concepts in a Greek Monastic Community on Mt Athos. Ph.D. dissertation, Department of Anthropology, LSE, London, UK.

Selwyn, Tom, ed. 1996. The Tourist Image: Myths and Myth Making in Tourism. Chichester: John Wiley \& Sons.

Seremetakis, Nadia. 1991. The Last Word: Women, Death, and Divination in Inner Mani. Chicago: University of Chicago Press.

Sidiropoulos, Georgios. 2000. Mount Athos: References in Anthropogeography. Athens: Kastanioti. 
Solomon, Esther, ed. 2021. Contested Antiquity: Archaeological Heritage and Social Conflict in Modern Greece and Cyprus. Bloomington: Indiana UP.

Speake, Graham. 2002. Mount Athos: Renewal in Paradise. New Haven and London: Yale UP.

Speake, Graham, and Dimitrios Conomos, eds. 2005. Mount Athos the Sacred Bridge: The Spirituality of the Holy Mountain. Oxford: Verlag Peter Lang.

Speake, Graham, and René Gothóni, eds. 2008. The Monastic Magnet: Roads to and from Mount Athos, 3rd ed. Oxford: Verlag Peter Lang. Taft, Robert. 2013. Perceptions and Realities in Orthodox-Catholic Relations Today. In Orthodox Constructions of the West. Edited by George Demacopoulos and Aristotle Papanikolaou. New York and Oxford: Fordham UP, pp. 23-44.

Tanasyuk, Pavlo, and Chrisanthi Avgerou. 2009. ICT and Religious Tradition: The Case of Mount Athos. Available online: http: / / \&lt; /named-content\&gt;eprints.lse.ac.uk/35560/ (accessed on 16 November 2020).

Theodossopoulos, Dimitrios. 2013. Laying Claim to Authenticity: Five anthropological dilemmas. Anthropology Quarterly 86: 337-60.

Tilson, Donn James. 2005. Religious-Spiritual Tourism and Promotional Campaigning: A Church-State Partnership for St. James and Spain. Journal of Hospitality \& Leisure Marketing 12: 9-40.

Turner, Victor. 1974. Dramas, Fields and Metaphors: Symbolic Action in Human Society. London: Cornell.

Turner, Victor. 1997. The Ritual Process: Structure and Antistructure. New Brunswick and London: Aldine Transaction.

Tzanelli, Rodanthi. 2008. Nation Building and Identity in Europe: The Dialogics of Reciprocity. Hampshire: Palgrave Macmillan.

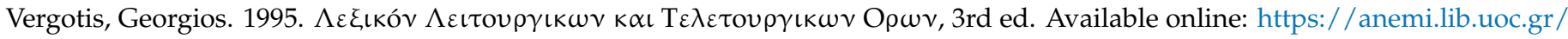
metadata/2/4/a/metadata-01-0001763.tkl (accessed on 23 March 2021).

Wang, Ning. 1999. Rethinking authenticity in tourism experience. Annals of Tourism Research 26: 349-70. [CrossRef]

Wang, Kuo-Yan, Azilah Kasim, and Jing Yu. 2020. Religious Festival Marketing: Distinguishing between devout believers and tourists. Religions 11: 413. [CrossRef]

Zatori, Anita, Melanie K. Smith, and Laszlo Puczko. 2018. Experience-involvement, memorability, and authenticity: The service provider's effect on tourist experience. Tourism Management 67: 110-26. [CrossRef]

Zhang, Hao, Taeyoung Cho, Huanjiong Wang, and Quansheng Ge. 2018. The Influence of Cross-Cultural Awareness and Tourist Experience on Authenticity, Tourist Satisfaction and Acculturation in World Cultural Heritage Sites of Korea. Sustainability 10: 927. Available online: https:/ /ideas.repec.org/a/gam/jsusta/v10y2018i4p927-d137640.html (accessed on 16 March 2021). [CrossRef] 